Review

\title{
The Cyanobacteria Derived Toxin Beta-N-Methylamino-L- Alanine and Amyotrophic Lateral Sclerosis
}

\author{
Sandra Anne Banack ${ }^{1} *$, Tracie A. Caller ${ }^{2}$ and Elijah W. Stommel ${ }^{2}$ \\ 1 The Institute for Ethnomedicine/PO Box 3464, Jackson, WY 83001, USA \\ 2 Department of Neurology, Dartmouth Hitchcock Medical Center/Lebanon, NH 03756, USA; \\ E-Mails: Tracie.A.Caller@Hitchcock.org (T.A.C.); Elijah.W.Stommel@Hitchcock.org (E.W.S.) \\ * Author to whom correspondence should be addressed; E-Mail: sandra @ethnomedicine.org; \\ Tel.: +1-801-375-6214; Fax: +1-801-373-3593.
}

Received: 29 November 2010; in revised form: 17 December 2010; / Accepted: 17 December 2010 / Published: 20 December 2010

\begin{abstract}
There is mounting evidence to suggest that environmental factors play a major role in the development of neurodegenerative diseases like ALS (Amyotrophic Lateral Sclerosis). The non-protein amino acid beta-N-methylamino-L-alanine (BMAA) was first associated with the high incidence of Amyotrophic Lateral Sclerosis/Parkinsonism Dementia Complex (ALS/PDC) in Guam, and has been implicated as a potential environmental factor in ALS, Alzheimer's disease, and other neurodegenerative diseases. BMAA has a number of toxic effects on motor neurons including direct agonist action on NMDA and AMPA receptors, induction of oxidative stress, and depletion of glutathione. As a non-protein amino acid, there is also the strong possibility that BMAA could cause intraneuronal protein misfolding, the hallmark of neurodegeneration. While an animal model for BMAA-induced ALS is lacking, there is substantial evidence to support a link between this toxin and ALS. The ramifications of discovering an environmental trigger for ALS are enormous. In this article, we discuss the history, ecology, pharmacology and clinical ramifications of this ubiquitous, cyanobacteria-derived toxin.
\end{abstract}

Keywords: Amyotrophic lateral sclerosis; Alzheimer's disease; cyanobacteria; Beta-N-methylamino-L-alanine; BMAA; epidemiology 


\section{Introduction}

Amyotrophic Lateral Sclerosis (ALS) is a debilitating and fatal neuromuscular disease with an average annual incidence worldwide of 2 per 100,000. Approximately 8-10\% of all cases are familial, about half of which are characterized by superoxide dismutase mutation (SOD-1). The other 90-92\% of ALS cases occur sporadically, with no known familial history. At present there is no known cause for sporadic ALS, though a number of environmental compounds have been implicated as potential etiological agents. The most documented and relatively well established toxicological risk factor for ALS is smoking [1-7]. Other associations that have been proposed are occupational exposure to electromagnetic radiation [8,9], contact with pesticides and heavy metals such as lead and mercury [10-16], and possibly exposure to formaldehyde [17]. Possible clusters of ALS have also been described amongst soccer players sharing the same environmental risks and occupational activities including frequent head trauma [18-24], but recent reports have also refuted specific links of head trauma to ALS [25-27]. Other forms of physical activity have been debated and despite many incidental reports, specific links with ALS have been refuted [28]. Of the environmental triggers for ALS, the cyanobacteria-derived neurotoxin BMAA continues to attract attention because of its ability to cause neurodegeneration in vitro and its ubiquitous nature [29,30,31-33], providing support for a potential role in the etiology of sporadic ALS [29,34,35].

\section{History of Guam and Initial Theory of BMAA}

When the United States recaptured the Marianas Islands in 1944 from Japan, they found an extremely high incidence rate of ALS and ALS-like conditions (ALS/ Parkinsonism dementia complex, ALS/PDC), particularly in Guam, where in 1954 it was estimated to be $50-100 \times$ higher than the worldwide rate [36-38]. Recent investigations suggest that the incidence and prevalence rates have declined considerably over the last 4 decades to levels of 7 per 100,000 that approach rates described in the rest of the world [39]. The disease also appears to have evolved over time to predominantly present clinically as parkinsonism and dementia rather than ALS. The chief factor responsible for the declining incidence appears to be ethnographic changes, social and ecological, brought about by the rapid westernization of Guam [39]. The change suggests that the cause of the disease is not genetic but rather environmental [39]. Early researchers suspected that something in cycad seeds, a dietary staple used by the Chamorro indigenous people to make flour, might be responsible for ALS/PDC [40]. The discovery of a neurotoxic non-protein amino acid, beta-N-methylamino-L-alanine (BMAA) in cycad flour suggested that this might be the particular cause of ALS/PDC [34,41]. BMAA in cycad seeds is derived from symbiotic cyanobacteria in coralloid roots of Cycas micronesica or possibly also from the cycad plant itself $[42,43]$. BMAA is mainly concentrated in proteins and was consumed by Chamorro through multiple dietary sources, including cycad flour, flying foxes (a type of fruit bat), and other animals that fed on cycad seeds [42,44-46].

\section{BMAA in Brain Tissue}

In the last ten years, Cox and colleagues have demonstrated that BMAA in cycad seeds is derived from symbiotic cyanobacteria in coralloid roots of Cycas micronesica and that BMAA in cycad flour 
is mainly concentrated in proteins. They were able to demonstrate that consumption of cycad flour, flying foxes, and other animals that fed on cycad seeds by the indigenous Chamorro people led to bioconcentration of protein-bound BMAA up the food chain, leading to the accumulation of BMAA in the brains of Chamorro patients with ALS/PDC (mean concentration of BMAA $627 \mu \mathrm{g} / \mathrm{g}$ ) [34,42,44-47]. BMAA has also been detected in the brains of Canadian patients with Alzheimer's disease (mean concentration of BMAA $107 \mu \mathrm{g} / \mathrm{g}$ ) but not in control patients without neurological disease [46]. This latter finding has recently been confirmed by a second group (mean concentration of BMAA in Alzheimer's brains $214 \mu \mathrm{g} / \mathrm{g}$ ) and extended to show that BMAA is accumulated in the brains of US ALS patients (mean concentration of BMAA $268 \mu \mathrm{g} / \mathrm{g}$ ), but not in those of patients with Huntington's disease, a genetic neurodegenerative disease (mean concentration of BMAA $11 \mu \mathrm{g} / \mathrm{g}$ ) or nonneurological controls (mean concentration of BMAA $41 \mu \mathrm{g} / \mathrm{g}$ ) [35]. Huntington's disease is purely a genetic neurodegenerative disease, so the inability to detect BMAA in these specimens is important as it suggests that BMAA does not occur as a byproduct of neurodegeneration.

\section{Molecular Mechanisms of BMAA}

Motor neurons are indisputably the largest and longest cells in the body making them vulnerable to any metabolic or external perturbation. Even fast retrograde and anterograde transport is a slow process in these very long axons moving at $100 \mathrm{~mm} /$ day. Because of the length of these cells, under the best of circumstances, it takes as much as two weeks for the fastest moving particles to go from the endplate to the cell body. Any small perturbation to transport or cellular hemostasis by an environmental toxin could have catastrophic effects. BMAA binds directly to NMDA and AMPA/kainate receptors and binding is enhanced when the BMAA is carbamated, producing a molecule that closely resembles glutamate $[48,49]$. BMAA has been found to induce selective motor neuron (MN) loss in dissociated mixed spinal cord cultures at concentrations of approximately $30 \mu \mathrm{M}$ [49], significantly lower than those previously found to induce widespread neuronal degeneration and supporting the hypothesis that BMAA may contribute to the selective MN loss in ALS/PDC [49,50]. Lobner et al. have shown that the mechanism of neurotoxicity is actually three-fold; it involves not only direct action on the NMDA receptor, but also activation of glutamate receptor 5 (mGluR5) and induction of oxidative stress [51]. More recently Liu et al. [52] found that BMAA inhibits the cystine/glutamate antiporter system $\mathrm{Xc}^{-}$mediated cystine uptake, which in turn leads to glutathione depletion and increased oxidative stress [52]. In cyclical-like pattern, BMAA appears to drive glutamate release via system $\mathrm{Xc}^{-}$which induces toxicity through activation of the mGluR5 receptor. These multiple mechanisms of BMAA toxicity may account for its ability to induce complex neurodegenerative diseases. As pointed out by Bradley and Mash [34], although a single toxin triggering three different neurodegenerative diseases seems unusual, we know that mutations in the progranulin gene can result in ALS, AD, PD and PSP phenotypes in North American patients [53-55].

Conceivably, BMAA could be incorporated into proteins and subsequently lead to protein misfolding. The mechanism of BMAA incorporation into protein is not yet known, but a large fraction of BMAA is protein bound (60 to 130 fold greater quantity) compared to what has been recovered from the free amino acid pool [46]. It is also known that amino acid analogues can be incorporated into proteins and can alter cell function [56]. It is not known if BMAA causes misfolding, but there is literature showing the misincorporation of even the regular 20 amino acids, as with disruption of 
translational fidelity through the use of low levels of mischarged transfer RNAs (tRNAs) [57]. This misincorporation is associated with protein misfolding in terminally differentiated neurons [57]. The incorporation of BMAA into protein serves as a potential reservoir for future release of the toxin into cells [46].

Although there are many examples where BMAA displays neurotoxicity, no good animal model exists as of yet [58]. BMAA has been shown to cause motor neuron damage in vivo in brine shrimp (Artemia salina [59]), protozoa (Nassula sorex [59]), fruit flies (Drosophila melanogaster [60]), and fish (Danio rerio [59,61]). For a meta-analysis of BMAA neurotoxicity in other vertebrates, including primates, see Karamyan and Speth [58].

The hypothesis that BMAA may be a cause of ALS has its detractors. Snyder et al. reported being unable to detect BMAA in the brains of patients with Alzheimer's disease and Guam ALS/PDC [62] and it has been pointed out that BMAA did not cause neurodegeneration in mice within their model system [62,63]. These observations have been criticized as being based on their own new assay methods rather than on the established AQC-derivatization assay and for not hydrolyzing the assayed material, thereby failing to release and measure the major portion of BMAA that is protein-bound $[32,34,58]$. Later papers from this same research team were able to find BMAA in the brain tissues of mice fed BMAA after they developed more sensitive analytical methods [64]. For whatever reason, the mouse model may be a poor model to demonstrate the neurotoxicity of BMAA and species-specific and allometric considerations are essential in these types of studies [58]. Despite these negative findings, the review by Karamyan and Speth [58] concluded that the neurotoxicity of BMAA was supported by almost all in vivo studies and is strongly associated with motor function.

\section{Potential Exposures to and Bioaccumulation of BMAA}

The production of BMAA is not confined to cycad seeds, and cyanobacteria species capable of producing BMAA are ubiquitously found throughout the world. In some locations, cyanobacteria are directly consumed by people and samples of these cyanobacteria have been shown to harbor BMAA. People from the Peruvian highlands collect cyanobacterial colonies of Nostoc commune (with a mean BMAA concentration of $10 \mu \mathrm{g} / \mathrm{g}$ ) and eat them directly, sell them in markets, and add them to salads, soups, meat dishes and picante [65]. Likewise, in China, fa cai soup made with Nostoc flageliforme (with variable concentrations of BMAA ranging from not detectable to $0.66 \mu \mathrm{g} / \mathrm{g}$ ) is eaten as a soup during New Year's celebrations [66]. Unfortunately, epidemiological and human tissue analyses in these areas are lacking and higher incidence rates of ALS and ALS-like diseases are unknown.

Cyanobacterial blooms can occur in both fresh water and marine water bodies, giving the potential for human exposure through direct consumption of water, recreational activities, and contaminated foodstuffs. In the United Kingdom, BMAA was prevalent in twelve water bodies used for either drinking water, recreation, or both [67]. BMAA was found within freeze-dried cyanobacteria collections obtained from these British water bodies as both a free amino acid (ranging from not detected to $276 \mu \mathrm{g} / \mathrm{g}$ ) and as a protein associated amino acid (ranging from 6 to $48 \mu \mathrm{g} / \mathrm{g}$ ). Likewise, BMAA has been indentified in scum material collected from urban waters in the Netherlands where cyanobacterial blooms are prevalent [68]. Recreational activities, such as swimming and water-skiing, are a potential source of exposure to BMAA in areas with cyanobacteria blooms; aerosol-borne exposure to another cyanobacteria toxin, microcystin, has already been documented [69,70]. In a 
recent article, Esterhuizen et al. [71] showed that free BMAA can be released during the collapse of cyanobacterial blooms. This process combined with cellular turnover creates a latent source of the non-protein amino acid for bioaccumulation and biomagnification in aquatic ecosystems. Rapid uptake of significant amounts of BMAA was observed in the macrophyte Ceratophyllum demersum [71]. Following accumulation of free BMAA, protein association was observed which suggests potential bioaccumulation by aquatic macrophytes and offers a possibility of phytoremediation for BMAA removal [71]. This also suggests a potential route for human exposure to BMAA if it is shown to apply more broadly to plants intended for human consumption. There is evidence to show that human exposure to other toxins of cyanobacterial origin occurs in this manner [72]. Bioaccumulation of BMAA is undoubtedly occurring within other organisms outside of the Guam ecosystem.

Recently, Brand et al. [73,74] found that BMAA is bio-concentrated in crustaceans, mollusks, and certain fish, particularly those that feed on the benthos. This study provides one plausible environmental source of the BMAA identified in the South Florida ALS and Alzheimer's disease patients described by Pablo et al. [35]; however, the very important correlative demographics and behaviors of individual patients are lacking at this time. The study by Brand et al. [74] has recently been confirmed in a second marine ecosystem in the Baltic Sea where the same pattern of high concentrations of BMAA was observed in bottom dwelling fish species and in filter-feeding mollusks [31]. Since massive blooms of cyanobacteria (e.g., Nodularia) are a common occurrence in the Baltic Sea because of its brackish waters and many organisms from the Baltic Sea are consumed by the surrounding human populations, this represents a concern for human health. Bioaccumulation of BMAA in marine environments is thus entirely feasible [75], but not demonstrated unequivocally as of yet. Caller et al. originally identified 9 ALS patients (now 11 ALS patients) who lived near Lake Mascoma in Enfield, NH, an incidence of sporadic ALS that is as much as 25 times the expected incidence for New Hampshire [76]. They suggested that the high incidence of ALS in this potential cluster might be related to a cyanobacteria toxin exposure from frequent cyanobacterial blooms in the lake. Blooms of cyanobacteria are found in many New Hampshire lakes each year and are capable of producing any number of toxins including BMAA [76]. Postulated mechanisms of BMAA acquisition include consuming contaminated fish, ingestion of lake water or possibly infiltration of lake water containing BMAA into artesian wells. Another postulated route of cyanotoxin exposure is inhalation of aerosolized toxins through wave action, as can occur with brevetoxins [77-80]. Besides wind and environmental factors, recreational activities in water bodies containing cyanobacterial blooms could potentially generate aerosolized cyanotoxins [70]. On an interesting note, cyanobacteria are major components of desert cryptobiotic soil crusts and BMAA was found in the desert crust of the Arabian Peninsula, where high winds constantly aerosolize the sand. Military activities in the Arabian Peninsula also created significant dust and more cases of ALS have been recorded in military personnel serving in this area during Gulf War I (Persian Gulf War) than in military personnel who were trained but not deployed [81].

\section{Multiple Exposures to Cyanobacterial Toxins}

Cyanobacteria are ubiquitous and produce a number of neurotoxins besides BMAA, including saxitoxin and anatoxin-a. Some species also produce the liver toxin microcystin which has been linked through careful epidemiological studies to liver disease and hepatocellular carcinoma [82-85]. BMAA 
has been shown to be co-produced with microcystin and other potent cyanobacterial toxins $[67,86]$. In addition, BMAA co-occurs with the neurotoxic isomer 2,4-diaminobutyric acid (2,4-DAB) in cycads and cyanobacteria $[68,81,87,88]$. It is established that not all cyanobacterial taxa are capable of producing some of the better characterized hepatic and neurologic toxins like microcystin, anatoxin-a, anatoxin-a(s), saxitoxin, and cylindrospermopsin. But, it is unclear at present whether all cyanobacteria are capable of producing BMAA under favorable conditions, and whether co-exposure to BMAA and other cyanobacterial toxins might potentiate the development of neurodegenerative disease. It is entirely possible that a synergistic effect could be created by exposure to more than one neurotoxin at a time. Lobner et al. demonstrated that in vitro, BMAA at concentrations as low as $10 \mu \mathrm{M}$ potentiate neuronal damage caused by other insults [51].

\section{Nutritional Status of Persons Exposed to BMAA}

Lathyrism or neurolathyrism is a neurological disease of humans and domestic animals, caused by consuming the legume Lathyrus sativus. The consumption of large quantities of Lathyrus sativus (400g/day) containing high concentrations of the glutamate analogue neurotoxin $\beta$ - $N$-oxalyl-amino-L-alanine (BOAA) causes a spastic paraparesis [89]. Lathyrism occurs during periods of malnutrition and is often triggered by physical exhaustion. Adverse environmental conditions brought on by drought, flood, pestilence and war have forced populations to rely almost exclusively on food resistant to these adverse conditions such as the Lathyrus sativus legume; a situation that leads to the development of Lathyrism [90]. Supplemental food-aid appears to reduce the incidence of neurolathyrism in areas of drought and malnutrition [91]. Jahan and Ahmad discovered that experimental neurolathyrism could be produced in guinea pigs and primates that needed an external supply of ascorbic acid by making them subclinically deficient in ascorbic acid and feeding them the seeds of Lathyrus sativus or extracts thereof [92]. Autoclaving the seeds of the Lathyrus sativus with lime removed the toxin [92]. As with BOAA, it is postulated that BMAA could be more harmful to malnourished individuals [93]. ALS/PDC was first discovered in Guam and peaked following World War II at a time when the indigenous Chamorro people were malnutritioned. By the time it was documented, dietary intake was probably back to near normal but years of malnutrition may have contributed to the overall peak of disease that occurred later.

\section{Latency Effects of BMAA}

The lag time between BMAA exposure and onset of neurodegeneration is not known, however, considerable insight can be found from the analysis of migrants to and from Guam. Twenty-eight Chamorro migrants from Guam developed ALS/PDC after periods of absence ranging from 1 to 34 years [94]. These data suggest that if environmental factors are responsible the latency period for disease development may be over three decades. Estimates of crude mortality rates from ALS for these migrants are at least three times as high as rates noted for the United States population, yet more than four times lower than the ALS crude mortality rates for non-migrant Chamorros living in Guam during the twenty years prior to the epidemiological study [94] suggesting that the exposure the migrants were subjected to occurred in Guam. When considering cases of progressive neurologicial disease among Filipino migrants to Guam, ten Filipino migrants to Guam were reported with ALS 1 to 32 years after 
their arrival; two migrants developed parkinsonism-dementia 13 and 26 years after arrival, and seven additional patients developed what was considered more classic PD 5 to 24 years after their migration to Guam [95]. Ten children born on Guam of Filipino and Chamorro parents also developed ALS and six developed PD [95]. The average annual crude mortality rate for ALS among Filipino migrants was estimated to be six times higher than those living in the continental United States but half the rate observed among Chamorros living on Guam during the same period [95]. Combined, these data suggest that environmental exposure precedes neurological symptoms by possibly decades and that some people are more susceptible to disease than others due to interactions between genes and environmental exposure.

\section{Conclusions}

Cyanobacteria are ubiquitous and many of the species examined so far have been shown to produce the neurotoxic non-protein amino acid BMAA. Since human exposure to BMAA appears to be widespread, it has the potential to be a major environmental factor capable of causing ALS and other neurodegenerative diseases throughout the world [34]. The literature is full of convincing spatial clusters of ALS and reports of conjugal ALS [24,76,96-103]. A careful evaluation of these clusters in relation to potential environmental sources of ALS would be very important as would evaluation of brain and spinal cord tissues for the presence of BMAA. Although the link between BMAA and sporadic ALS awaits a primate model of BMAA-induced progressive neurodegeneration for better confirmation [58], multi-disciplinary studies by investigators at a variety of institutions indicate that BMAA should be more carefully investigated as a trigger for ALS acting through gene-environment interactions.

\section{References}

1. Weisskopf, M.G.; Ascherio, A. Cigarettes and amyotrophic lateral sclerosis: Only smoke or also fire? Ann. Neurol. 2009, 65, 361-362.

2. Kamel, F.; Umbach, D.M.; Munsat, T.L.; Shefner, J.M.; Sandler, D.P. Association of cigarette smoking with amyotrophic lateral sclerosis. Neuroepidemiology 1999, 18, 194-202.

3. Alonso, A.; Logroscino, G.; Jick, S.S.; Hernan, M.A. Association of smoking with amyotrophic lateral sclerosis risk and survival in men and women: A prospective study. BMC Neurol. 2010, 6, doi:10.1186/1471-2377-10-6.

4. Armon, C. Smoking may be considered an established risk factor for sporadic ALS. Neurology 2009, 73, 1693-1698.

5. Fang, F.; Ye, W. Smoking may be considered an established risk factor for sporadic ALS. Neurology 2010, 74, 1927;

6. Weisskopf, M.J.; Gallo, V.; O'Reilly, E.J.; Vineis, P.; Ascherio, A. Smoking may be considered an established risk factor for sporadic ALS. Neurology 2010, 74, 1927-1928;

7. Gallo, V.; Bueno-De-Mesquita, H.B.; Vermeulen, R.; Andersen, P.M.; Kyrozis, A.; Linseisen, J.; Kaaks, R.; Allen, N.E.; Roddam, A.W.; Boshuizen, H.C.; Peeters, P.H.; Palli, D.; Mattiello, A.; Sieri, S.; Tumino, R.; Jimenez-Martin, J.M.; Diaz, M.J.; Suarez, L.R.; Trichopoulou, A.; Agudo, A.; Arriola, L.; Barricante-Gurrea, A.; Bingham, S.; Khaw, K.T.; Manjer, J.; Lindkvist, B.; 
Overvad, K.; Bach, F.W.; Tjonneland, A.; Olsen, A.; Bergmann, M.M.; Boeing, H.; ClavelChapelon, F.; Lund, E.; Hallmans, G.; Middleton, L.; Vineis, P.; Riboli, E. Smoking and risk for amyotrophic lateral sclerosis: Analysis of the EPIC cohort. Ann. Neurol. 2009, 65, 378-385.

8. Hakansson, N.; Gustavsson, P.; Johansen, C.; Floderus, B. Neurodegenerative diseases in welders and other workers exposed to high levels of magnetic fields. Epidemiology 2003, 14, 420-426;

9. Li, C.Y.; Sung, F.C. Association between occupational exposure to power frequency electromagnetic fields and amyotrophic lateral sclerosis: A review. Am. J. Ind. Med. 2003, 43, 212-220.

10. Johnson, F.O.; Atchison, W.D. The role of environmental mercury, lead and pesticide exposure in development of amyotrophic lateral sclerosis. Neurotoxicology 2009, 30, 761-765.

11. McGuire, V.; Longstreth, W.T., Jr.; Nelson, L.M.; Koepsell, T.D.; Checkoway, H.; Morgan, M.S.; van Belle, G. Occupational exposures and amyotrophic lateral sclerosis. A populationbased case-control study. Am. J. Epidemiol. 1997, 145, 1076-1088.

12. Kamel, F.; Umbach, D.M.; Hu, H.; Munsat, T.L.; Shefner, J.M.; Taylor, J.A.; Sandler, D.P. Lead exposure as a risk factor for amyotrophic lateral sclerosis. Neurodegener. Dis. 2005, 2, 195-201.

13. Kamel, F.; Umbach, D.M.; Lehman, T.A.; Park, L.P.; Munsat, T.L.; Shefner, J.M.; Sandler, D.P.; $\mathrm{Hu}, \mathrm{H}$; Taylor, J.A. Amyotrophic lateral sclerosis, lead, and genetic susceptibility: Polymorphisms in the delta-aminolevulinic acid dehydratase and vitamin D receptor genes. Environ. Health Perspect. 2003, 111, 1335-1339.

14. Kamel, F.; Umbach, D.M.; Munsat, T.L.; Shefner, J.M.; Hu, H.; Sandler, D.P. Lead exposure and amyotrophic lateral sclerosis. Epidemiology 2002, 13, 311-319.

15. Kamel, F.; Umbach, D.M.; Stallone, L.; Richards, M.; Hu, H.; Sandler, D.P. Association of lead exposure with survival in amyotrophic lateral sclerosis. Environ. Health Perspect. 2008, 116, 943-947.

16. Morahan, J.M.; Pamphlett, R. Amyotrophic lateral sclerosis and exposure to environmental toxins: an Australian case-control study. Neuroepidemiology 2006, 27, 130-135.

17. Weisskopf, M.G.; Morozova, N.; O'Reilly, E.J.; McCullough, M.L.; Calle, E.E.; Thun, M.J.; Ascherio, A. Prospective study of chemical exposures and amyotrophic lateral sclerosis. J. Neurol. Neurosurg. Psychiatry 2009, 80, 558-561.

18. McKee, A.C.; Gavett, B.E.; Stern, R.A.; Nowinski, C.J.; Cantu, R.C.; Kowall, N.W.; Perl, D.P.; Hedley-Whyte, E.T.; Price, B.; Sullivan, C.; Morin, P.; Lee, H.S.; Kubilus, C.A.; Daneshvar, D.H.; Wulff, M.; Budson, A.E. TDP-43 proteinopathy and motor neuron disease in chronic traumatic encephalopathy. J. Neuropathol. Exp. Neurol. 2010, 69, 918-929.

19. Schmidt, S.; Kwee, L.C.; Allen, K.D.; Oddone, E.Z. Association of ALS with head injury, cigarette smoking and APOE genotypes. J. Neurol. Sci. 291, 22-29.

20. Belli, S.; Vanacore, N. Proportionate mortality of Italian soccer players: Is amyotrophic lateral sclerosis an occupational disease? Eur. J. Epidemiol. 2005, 20, 237-242.

21. Chio, A.; Traynor, B.J.; Swingler, R.; Mitchell, D.; Hardiman, O.; Mora, G.; Beghi, E.; Logroscino, G. Amyotrophic lateral sclerosis and soccer: A different epidemiological approach strengthen the previous findings. J. Neurol. Sci. 2008, 269, 187-188. 
22. Piazza, O.; Siren, A.L.; Ehrenreich, H. Soccer, neurotrauma and amyotrophic lateral sclerosis: Is there a connection? Curr. Med. Res. Opin. 2004, 20, 505-508.

23. Altavista, P.; Belli, S.; Binazzi, A.; Comba, P.; Mastrantonio, M.; Uccelli, R.; Vanacore, N. Increase in mortality for motor neuron disease in Italy, 1980-1999. Epidemiol. Prev. 2006, 30, 108-113.

24. Wicks, P.; Ganesalingham, J.; Collin, C.; Prevett, M.; Leigh, N.P.; Al-Chalabi, A. Three soccer playing friends with simultaneous amyotrophic lateral sclerosis. Amyotroph Lateral Scler 2007, $8,177-179$.

25. Appel, S.H.; Cwik, V.A.; Day, J.W. Trauma, TDP-43, and amyotrophic lateral sclerosis. Muscle Nerve 2010, 42, 851-852.

26. Turner, M.R.; Abisgold, J.; Yeates, D.G.; Talbot, K.; Goldacre, M.J. Head and other physical trauma requiring hospitalisation is not a significant risk factor in the development of ALS. J. Neurol. Sci. 2010, 288, 45-48.

27. Bazarian, J.J.; Cernak, I.; Noble-Haeusslein, L.; Potolicchio, S.; Temkin, N. Long-term neurologic outcomes after traumatic brain injury. J. Head Trauma Rehabil.2009, 24, 439-451.

28. Longstreth, W.T.; McGuire, V.; Koepsell, T.D.; Wang, Y.; van Belle, G. Risk of amyotrophic lateral sclerosis and history of physical activity: A population-based case-control study. Arch. Neurol. 1998, 55, 201-206.

29. Ince, P.G.; Codd, G.A. Return of the cycad hypothesis-Does the amyotrophic lateral sclerosis/parkinsonism dementia complex (ALS/PDC) of Guam have new implications for global health? Neuropathol. Appl. Neurobiol. 2005, 31, 345-353.

30. Papapetropoulos, S. Is there a role for naturally occurring cyanobacterial toxins in neurodegeneration? The beta-N-methylamino-L-alanine (BMAA) paradigm. Neurochem. Int. 2007, 50, 998-1003.

31. Jonasson, S.; Eriksson, J.; Berntzon, L.; Spacil, Z.; Ilag, L.L.; Ronnevi, L.O.; Rasmussen, U.; Bergman, B. Transfer of a cyanobacterial neurotoxin within a temperate aquatic ecosystem suggests pathways for human exposure. Proc. Natl. Acad. Sci. USA 2001, 107, 9252-9257.

32. Bradley, W.G.; Banack, S.A.; Cox, P.A. The ALS/PDC syndrome of Guam and the cycad hypothesis. Neurology 2009, 72, 473-474, 476.

33. Nunn, P.B.; Ponnusamy, M. Beta-N-methylaminoalanine (BMAA): Metabolism and metabolic effects in model systems and in neural and other tissues of the rat in vitro. Toxicon 2009, 54, 85-94.

34. Bradley, W.G.; Mash, D.C. Beyond Guam: the cyanobacteria/BMAA hypothesis of the cause of ALS and other neurodegenerative diseases. Amyotroph Lateral Scler 2009, 10 (Suppl. 2), 7-20.

35. Pablo, J.; Banack, S.A.; Cox, P.A.; Johnson, T.E.; Papapetropoulos, S.; Bradley, W.G.; Buck, A.; Mash, D.C. Cyanobacterial neurotoxin BMAA in ALS and Alzheimer's disease. Acta. Neurol. Scand. 2009, 120, 216-225.

36. Mulder, D.W.; Kurland, L.T. Motor neuron disease: epidemiologic studies. Adv. Exp. Med. Biol. 1987, 209, 325-332.

37. Kurland, L.T.; Mulder, D.W. Epidemiologic investigations of amyotrophic lateral sclerosis. I. Preliminary report on geographic distribution and special reference to the Mariana Islands, including clinical and pathologic observations. Neurology 1954, 4, 438-448. 
38. Zimmerman, H.M. Monthly Report to the Medical Officer in Command; United States Navy Medical Research Unit: Dayton, OH, USA, 1945.

39. Plato, C.C.; Garruto, R.M.; Galasko, D.; Craig, U.K.; Plato, M.; Gamst, A.; Torres, J.M.; Wiederholt, W. Amyotrophic lateral sclerosis and parkinsonism-dementia complex of Guam: changing incidence rates during the past 60 years. Am. J. Epidemiol. 2003, 157, 149-157.

40. Whiting, M.G. Toxicity of Cycads: A Literature Review. Econ. Bot. 1963, 17, 270-302.

41. Spencer, P.S.; Hugon, J.; Ludolph, A.; Nunn, P.B.; Ross, S.M.; Roy, D.N.; Schaumburg, H.H. Discovery and partial characterization of primate motor-system toxins. Ciba Found. Symp. 1987, 126, 221-238.

42. Banack, S.A.; Cox, P.A. Biomagnification of cycad neurotoxins in flying foxes: implications for ALS-PDC in Guam. Neurology 2003, 61, 387-389.

43. Brenner, E.D.; Stevenson, D.W.; McCombie, R.W.; Katari, M.S.; Rudd, S.A.; Mayer, K.F.; Palenchar, P.M.; Runko, S.J.; Twigg, R.W.; Dai, G.; Martienssen, R.A.; Benfey, P.N.; Coruzzi, G.M. Expressed sequence tag analysis in Cycas, the most primitive living seed plant. Genome Biol. 2003, 4, R78.

44. Cox, P.A.; Sacks, O.W. Cycad neurotoxins, consumption of flying foxes, and ALS-PDC disease in Guam. Neurology 2002, 58, 956-959.

45. Banack, S.A.; Murch, S.J.; Cox, P.A. Neurotoxic flying foxes as dietary items for the Chamorro people, Marianas Islands. J. Ethnopharmacol. 2006, 106, 97-104.

46. Murch, S.J.; Cox, P.A.; Banack, S.A. A mechanism for slow release of biomagnified cyanobacterial neurotoxins and neurodegenerative disease in Guam. Proc. Natl. Acad. Sci. USA 2004, 101, 12228-12231.

47. Murch, S.J.; Cox, P.A.; Banack, S.A.; Steele, J.C.; Sacks, O.W. Occurrence of betamethylamino-l-alanine (BMAA) in ALS/PDC patients from Guam. Acta. Neurol. Scand. 2004, $110,267-269$.

48. Weiss, J.H.; Koh, J.Y.; Choi, D.W. Neurotoxicity of beta-N-methylamino-L-alanine (BMAA) and beta-N-oxalylamino-L-alanine (BOAA) on cultured cortical neurons. Brain Res. 1989, 497, 64-71.

49. Rao, S.D.; Banack, S.A.; Cox, P.A.; Weiss, J.H. BMAA selectively injures motor neurons via AMPA/kainate receptor activation. Exp. Neurol. 2006, 201, 244-252.

50. Vyas, K.J.; Weiss, J.H. BMAA-An unusual cyanobacterial neurotoxin. Amyotroph Lateral Scler 2009, 10 (Suppl. 2), 50-55.

51. Lobner, D.; Piana, P.M.; Salous, A.K.; Peoples, R.W. Beta-N-methylamino-L-alanine enhances neurotoxicity through multiple mechanisms. Neurobiol Dis. 2007, 25, 360-366.

52. Liu, X.; Rush, T.; Zapata, J.; Lobner, D. beta-N-methylamino-l-alanine induces oxidative stress and glutamate release through action on system Xc(-). Exp. Neurol. 2009, 217, 429-433.

53. Brouwers, N.; Nuytemans, K.; van der Zee, J.; Gijselinck, I.; Engelborghs, S.; Theuns, J.; Kumar-Singh, S.; Pickut, B.A.; Pals, P.; Dermaut, B.; Bogaerts, V.; De Pooter, T.; Serneels, S.; Van den Broeck, M.; Cuijt, I.; Mattheijssens, M.; Peeters, K.; Sciot, R.; Martin, J.J.; Cras, P.; Santens, P.; Vandenberghe, R.; De Deyn, P.P.; Cruts, M.; Van Broeckhoven, C.; Sleegers, K. Alzheimer and Parkinson diagnoses in progranulin null mutation carriers in an extended founder family. Arch. Neurol. 2007, 64, 1436-1446. 
54. Spina, S.; Murrell, J.R.; Huey, E.D.; Wassermann, E.M.; Pietrini, P.; Grafman, J.; Ghetti, B. Corticobasal syndrome associated with the A9D Progranulin mutation. J. Neuropathol. Exp. Neurol. 2007, 66, 892-900.

55. Wider, C.; Uitti, R.J.; Wszolek, Z.K.; Fang, J.Y.; Josephs, K.A.; Baker, M.C.; Rademakers, R.; Hutton, M.L.; Dickson, D.W. Progranulin gene mutation with an unusual clinical and neuropathologic presentation. Mov. Disord. 2008, 23, 1168-1173.

56. Rodgers, K.J.; Shiozawa, N. Misincorporation of amino acid analogues into proteins by biosynthesis. Int. J. Biochem. Cell Biol. 2008, 40 1452-1466.

57. Lee, J.W.; Beebe, K.; Nangle, L.A.; Jang, J.; Longo-Guess, C.M.; Cook, S.A.; Davisson, M.T.; Sundberg, J.P.; Schimmel, P.; Ackerman, S.L. Editing-defective tRNA synthetase causes protein misfolding and neurodegeneration. Nature 2006, 443, 50-55.

58. Karamyan, V.T.; Speth, R.C. Animal models of BMAA neurotoxicity: A critical review. Life Sci. 2008, 82, 233-246.

59. Purdie, E.L.; Metcalf, J.S.; Kashmiri, S.; Codd, G.A. Toxicity of the cyanobacterial neurotoxin beta-N-methylamino-L-alanine to three aquatic animal species. Amyotroph Lateral Scler 2009, 10 (Suppl. 2), 67-70.

60. Zhou, X.; Escala, W.; Papapetropoulos, S.; Bradley, W.G.; Zhai, R.G. BMAA neurotoxicity in Drosophila. Amyotroph Lateral Scler 2009, 10 (Suppl. 2), 61-66.

61. Purdie, E.L.; Samsudin, S.; Eddy, F.B.; Codd, G.A. Effects of the cyanobacterial neurotoxin beta-N-methylamino-L-alanine on the early-life stage development of zebrafish (Danio rerio). Aquat. Toxicol. 2009, 95, 279-284.

62. Snyder, L.R.; Cruz-Aguado, R.; Sadilek, M.; Galasko, D.; Shaw, C.A.; Montine, T.J. Lack of cerebral bmaa in human cerebral cortex. Neurology 2009, 72, 1360-1361.

63. Snyder, L.R.; Cruz-Aguado, R.; Sadilek, M.; Galasko, D.; Shaw, C.A.; Montine, T.J. Parkinsondementia complex and development of a new stable isotope dilution assay for BMAA detection in tissue. Toxicol. Appl. Pharmacol. 2009, 240, 180-188.

64. Snyder, L.R.; Hoggard, J.C.; Montine, T.J.; Synovec, R.E. Development and application of a comprehensive two-dimensional gas chromatography with time-of-flight mass spectrometry method for the analysis of L-beta-methylamino-alanine in human tissue. J. Chromatogr. A 2010, $1217,4639-4647$.

65. Johnson, H.E.; King, S.R.; Banack, S.A.; Webster, C.; Callanaupa, W.J.; Cox, P.A. Cyanobacteria (Nostoc commune) used as a dietary item in the Peruvian highlands produce the neurotoxic amino acid BMAA. J. Ethnopharmacol. 2008, 118, 159-165.

66. Roney, B.R.; Renhui, L.; Banack, S.A.; Murch, S.; Honegger, R.; Cox, P.A. Consumption of fa cai Nostoc soup: A potential for BMAA exposure from Nostoc cyanobacteria in China? Amyotroph Lateral Scler 2009, 10 (Suppl. 2), 44-49.

67. Metcalf, J.S.; Banack, S.A.; Lindsay, J.; Morrison, L.F.; Cox, P.A.; Codd, G.A. Co-occurrence of beta-N-methylamino-L-alanine, a neurotoxic amino acid with other cyanobacterial toxins in British waterbodies, 1990-2004. Environ. Microbiol. 2008, 10, 702-708. 
68. Faassen, E.J.; Gillissen, F.; Zweers, H.A.; Lurling, M. Determination of the neurotoxins BMAA (beta-N-methylamino-L-alanine) and DAB (alpha-,gamma-diaminobutyric acid) by LC-MSMS in Dutch urban waters with cyanobacterial blooms. Amyotroph Lateral Scler 2009, 10 (Suppl. 2), 79-84.

69. Backer, L.C.; Carmichael, W.; Kirkpatrick, B.; Williams, C.; Irvin, M.; Zhou, Y.; Johnson, T.B.; Nierenberg, K.; Hill, V.R.; Kieszak, S.M.; Cheng, Y.S. Recreational exposure to low concentrations of microcystins during an algal bloom in a small lake. Mar. Drugs 2008, 6, 389-406.

70. Backer, L.C.; McNeel, S.V.; Barber, T.; Kirkpatrick, B.; Williams, C.; Irvin, M.; Zhou, Y.; Johnson, T.B.; Nierenberg, K.; Aubel, M.; LePrell, R.; Chapman, A.; Foss, A.; Corum, S.; Hill, V.R.; Kieszak, S.M.; Cheng, Y.S. Recreational exposure to microcystins during algal blooms in two California lakes. Toxicon 2001, 55, 909-921.

71. Esterhuizen, M.; Pflugmacher, S.; Downing, T.G. Beta-N-Methylamino-l-alanine (BMAA) uptake by the aquatic macrophyte Ceratophyllum demersum. Ecotoxicol. Environ. Saf. 2011, 74, 74-7.

72. Codd, G.A.; Bell, S.G.; Kaya, K.; Ward, C.J.; Beattie, K.A.; Metcalf, J.S. Cyanobacterial toxins, exposure routes and human health. Eur. J. Phycol. 1999, 34, 405-415.

73. Brand, L.E. Human exposure to cyanobacteria and BMAA. Amyotroph Lateral Scler 2009, 10 (Suppl. 2), 85-95.

74. Brand, L.E.; Pablo, J. Cyanobacterial blooms and the occurrence of the neurotoxin, beta-N-methylamino-L-alanine (BMAA), in South Florida aquatic food webs. Harmful Algae 2010, 9, doi:10.1016/j.hal.2010.05.002.

75. Banack, S.A.; Johnson, H.E.; Cheng, R.; Cox, P.A. Production of the Neurotoxin BMAA by a Marine Cyanobacterium. Mar. Drugs 2007, 5, 180-196.

76. Caller, T.A.; Doolin, J.W.; Haney, J.F.; Murby, A.J.; West, K.G.; Farrar, H.E.; Ball, A.; Harris, B.T.; Stommel, E.W. A cluster of amyotrophic lateral sclerosis in New Hampshire: A possible role for toxic cyanobacteria blooms. Amyotroph Lateral Scler 2009, 10 (Suppl. 2), 101-108.

77. Fleming, L.E.; Bean, J.A.; Kirkpatrick, B.; Cheng, Y.S.; Pierce, R.; Naar, J.; Nierenberg, K.; Backer, L.C.; Wanner, A.; Reich, A.; Zhou, Y.; Watkins, S.; Henry, M.; Zaias, J.; Abraham, W.M.; Benson, J.; Cassedy, A.; Hollenbeck, J.; Kirkpatrick, G.; Clarke, T.; Baden, D.G. Exposure and effect assessment of aerosolized red tide toxins (brevetoxins) and asthma. Environ. Health Perspect. 2009, 117, 1095-1100.

78. Fleming, L.E.; Kirkpatrick, B.; Backer, L.C.; Bean, J.A.; Wanner, A.; Reich, A.; Zaias, J.; Cheng, Y.S.; Pierce, R.; Naar, J.; Abraham, W.M.; Baden, D.G. Aerosolized red-tide toxins (brevetoxins) and asthma. Chest 2007, 131, 187-194.

79. Lee, R.U.; Woessner, K.M.; Mathison, D.A. Surfer's asthma. Allergy Asthma Proc. 2009, 30, 202-205.

80. Yan, X.; Benson, J.M.; Gomez, A.P.; Baden, D.G.; Murray, T.F. Brevetoxin-induced neural insult in the retrosplenial cortex of mouse brain. Inhal. Toxicol. 2006, 18, 1109-1116.

81. Cox, P.A.; Richer, R.; Metcalf, J.S.; Banack, S.A.; Codd, G.A.; Bradley, W.G. Cyanobacteria and BMAA exposure from desert dust: A possible link to sporadic ALS among Gulf War veterans. Amyotroph Lateral Scler 2009, 10 (Suppl. 2), 109-117. 
82. Fleming, L.E.; Rivero, C.; Burns, J.; Williams, C.; Beana, J.A.; Shea, K.A.; Stinn, J. Blue-green algae (cyanobacterial) toxins, surface drinking water, and liver cancer in Florida. Harmful Algae 2002, 1, 157-168.

83. Nishiwaki-Matsushima, R.; Ohta, T.; Nishiwaki, S.; Suganuma, M.; Kohyama, K.; Ishikawa, T.; Carmichael, W.W.; Fujiki, H. Liver tumor promotion by the cyanobacterial cyclic peptide toxin microcystin-LR. J. Cancer Res. Clin. Oncol. 1992, 118, 420-424.

84. Svircev, Z.; Krstic, S.; Miladinov-Mikov, M.; Baltic, V.; Vidovic, M. Freshwater cyanobacterial blooms and primary liver cancer epidemiological studies in Serbia. J. Environ. Sci. Health C Environ. Carcinog. Ecotoxicol. Rev. 2009, 27, 36-55.

85. Yu, S.Z. Primary prevention of hepatocellular carcinoma. J. Gastroenterol. Hepatol. 1995, 10, 674-682.

86. Cox, P.A.; Banack, S.A.; Murch, S.J.; Rasmussen, U.; Tien, G.; Bidigare, R.R.; Metcalf, J.S.; Morrison, L.F.; Codd, G.A.; Bergman, B. Diverse taxa of cyanobacteria produce beta-Nmethylamino-L-alanine, a neurotoxic amino acid. Proc. Natl. Acad. Sci. USA 2005, 102, 5074-5078.

87. Banack, S.A.; Murch, S.J. Multiple neurotoxic items in the Chamorro diet link BMAA with ALS/PDC. Amyotroph Lateral Scler 2009, 10 (Suppl. 2), 34-40.

88. Craighead, D.; Metcalf, J.S.; Banack, S.A.; Amgalan, L.; Reynolds, H.V.; Batmunkh, M. Presence of the neurotoxic amino acids beta-N-methylamino-L-alanine (BMAA) and 2,4diamino-butyric acid (DAB) in shallow springs from the Gobi Desert. Amyotroph Lateral Scler 2009, 10 (Suppl. 2), 96-100.

89. Ludolph, A.C.; Spencer, P.S. Toxic models of upper motor neuron disease. J. Neurol. Sci. 1996, 139, 53-59.

90. Spencer, P.S., Lathyrism. In Handbook of Clinical Neurology; Vinken, B.G., Ed. Elsevier: Amsterdam, The Netherlands, 1994; pp. 1-20.

91. Getahun, H.; Lambein, F.; Vanhoorne, M.; Van der Stuyft, P. Food-aid cereals to reduce neurolathyrism related to grass-pea preparations during famine. Lancet 2003, 362, 1808-1810.

92. Jahan, K.; Ahmad, K. Studies on neurolathyrism. Environ. Res. 1993, 60, 259-266.

93. Smith, Q.R.; Nagura, H.; Takada, Y.; Duncan, M.W. Facilitated transport of the neurotoxin, betaN-methylamino-L-alanine, across the blood-brain barrier. J. Neurochem. 1992, 58, 1330-1337.

94. Garruto, R.M.; Gajdusek, C.; Chen, K.M. Amyotrophic lateral sclerosis among Chamorro migrants from Guam. Ann. Neurol. 1980, 8, 612-619.

95. Garruto, R.M.; Gajdusek, D.C.; Chen, K.M. Amyotrophic lateral sclerosis and parkinsonismdementia among Filipino migrants to Guam. Ann. Neurol. 1981, 10, 341-350.

96. Corcia, P.; Jafari-Schluep, H.F.; Lardillier, D.; Mazyad, H.; Giraud, P.; Clavelou, P.; Pouget, J.; Camu, W. A clustering of conjugal amyotrophic lateral sclerosis in southeastern France. Arch. Neurol. 2003, 60, 553-557.

97. Poloni, M.; Micheli, A.; Facchetti, D.; Mai, R.; Ceriani, F.; Cattalini, C. Conjugal amyotrophic lateral sclerosis: Toxic clustering or change? Ital. J. Neurol. Sci. 1997, 18, 109-112.

98. Uccelli, R.; Binazzi, A.; Altavista, P.; Belli, S.; Comba, P.; Mastrantonio, M.; Vanacore, N. Geographic distribution of amyotrophic lateral sclerosis through motor neuron disease mortality data. Eur. J. Epidemiol. 2007, 22, 781-790. 
99. Scott, K.M.; Abhinav, K.; Stanton, B.R.; Johnston, C.; Turner, M.R.; Ampong, M.A.; Sakel, M.; Orrell, R.W.; Howard, R.; Shaw, C.E.; Leigh, P.N.; Al-Chalabi, A. Geographical clustering of amyotrophic lateral sclerosis in South-East England: A population study. Neuroepidemiology 2009, 32, 81-88.

100. Sabel, C.E.; Boyle, P.J.; Loytonen, M.; Gatrell, A.C.; Jokelainen, M.; Flowerdew, R.; Maasilta, P. Spatial clustering of amyotrophic lateral sclerosis in Finland at place of birth and place of death. Am. J. Epidemiol. 2003, 157, 898-905.

101. Melmed, C.; Krieger, C. A cluster of amyotrophic lateral sclerosis. Arch. Neurol. 1982, 39, 595-596.

102. Gunnarsson, L.G.; Lygner, P.E.; Veiga-Cabo, J.; de Pedro-Cuesta, J. An epidemic-like cluster of motor neuron disease in a Swedish county during the period 1973-1984. Neuroepidemiology 1996, 15, 142-152.

103. Sienko, D.G.; Davis, J.P.; Taylor, J.A.; Brooks, B.R. Amyotrophic lateral sclerosis. A casecontrol study following detection of a cluster in a small Wisconsin community. Arch. Neurol. 1990, 47, 38-41.

(C) 2010 by the authors; licensee MDPI, Basel, Switzerland. This article is an open-access article distributed under the terms and conditions of the Creative Commons Attribution license (http://creativecommons.org/licenses/by/3.0/). 